\title{
ANALISIS PENENTUAN HARGA JUAL BATUBARA PT BERAU COAL UNTUK PEMBANGKIT LISTRIK TENAGA UAP MULUT TAMBANG LATI
}

\section{Determination Analysis for Coal Selling Price of PT Berau Coal for Lati's Mine Mouth Power Plant}

\author{
IJANG SUHERMAN dan BAMBANG YUNIANTO \\ Puslitbang Teknologi Mineral dan Batubara \\ Jalan Jenderal Sudirman 623 Bandung 40211 \\ Telp. (022) 6030483, Fax. (022) 6003373 \\ e-mail: ljang@tekmira.esdm.go.id
}

\begin{abstract}
ABSTRAK
Perusahaan batubara dalam hal menjual batubara harus mengikuti peraturan yang dikeluarkan oleh Kementerian Energi dan Sumber Daya Mineral yang kewenangannya ada di bawah Direktorat Jenderal Mineral dan Batubara. PT Berau Coal sejak 2003 menjual batubara berupa reject coal kepada Pembangkit Listrik Tenaga Uap Mulut Tambang Lati di Kabupaten Berau, Kalimantan Timur. Berdasarkan kajian Pusat Penelitian dan Pengembangan Teknologi Mineral dan Batubara, harga jual batubara tersebut ditetapkan sebesar USD 0,85 per ton atau senilai bagi hasil bagian pemerintah, dengan pertimbangan untuk memajukan daerah. Dengan berjalannya waktu, cadangan reject coal perusahaan tambang tersebut semakin tipis. Di samping itu, penggunaan reject coal untuk pembangkit listrik menimbulkan permasalahan bagi boiler. Untuk memenuhi kebutuhan pembangkit listrik tersebut, sebagai alternatif digunakan batubara non reject coal yang tersedia di pasar batubara. Harga batubara untuk steam (thermal) coal ditetapkan berdasarkan Harga Patokan Batubara. Kondisi tersebut menjadi kendala, khususnya untuk periode 2012-2015, yaitu belum adanya kesepakatan harga jual beli dari kedua belah pihak. Berdasarkan analisis, harga tersebut tidak ekonomis bagi pembangkit listrik tersebut (PT Indo Pusaka Berau) maupun PT PLN. Di lain pihak, berdasarkan simulasi cash flow PT Indo Pusaka Berau, jika harga batubara senilai bagian pemerintah, biaya produksi lebih ekonomis, tetapi tidak sesuai lagi dengan peraturan. Untuk mencari winwin solution terhadap persoalan tersebut, maka berdasarkan Pasal 2 dan 3 Peraturan Direktur Jenderal Mineral dan Batubara Nomor 1348.K/30/DJB/2011, bahwa harga batubara untuk pembangkit listrik mulut tambang dengan kalori lebih besar atau sama dengan $3.000 \mathrm{kkal} / \mathrm{kg}$ gar dapat dijual dengan harga di bawah Harga Patokan Batubara dengan menyampaikan kajian. Berdasarkan hasil analisis diperoleh satu harga alternatif, yaitu USD 19,96 per ton.
\end{abstract}

Kata kunci: reject coal, bagi hasil, steam (thermal) coal, harga patokan batubara, pembangkit listrik tenaga uap mulut tambang

\begin{abstract}
Coal company in selling coal must follow the regulations issued by the Ministry of Energy and Mineral Resources, in which the authority is under the Directorate General of Mineral and Coal. PT Berau Coal since 2003 had been selling coal in the form of reject coal to Steam Power Plant Mine Mouth Lati in Berau, East Kalimantan. Based on study of the R\&D Centre for Mineral and Coal Tecnology, the selling prices of the coal is set at USD 0.85 per ton, or equivalent for the share of the government, with consideration to advance the region. Over time, the company's reject coal reserves decline. In addition, the use of reject coal for the powers creates problems for the boiler. Therefore, to meet the needs of Lati Mouth Steam Power Plant, the alternative is to use
\end{abstract}


non-reject coal, which is available in the coal market. Coal price for steam (thermal) coal is determined based on Coal Benchmark Price. These conditions become constraints, especially for the period 2012-2015, namely the absence of agreement on the purchase price of both parties. Based on the analysis, with reference to the benchmark price of coal, the selling price of the company becomes not economical for Lati Mouth Power Plant (PT Indo Pusaka Berau) and PT PLN. On the other side, based on simulated cash flow of PT Indo Pusaka, if the price of coal is equal to the part of the government, then the production cost is more economically, however, is not in accordance with the regulation. To find a win win solution to the problem, based on Article 2 and 3 of Regulation of Director General of Mineral and Coal Number 1348.K/30/DJB/2011, that the price of coal for mine mouth power plant with more calories than or equal to 3,000 $\mathrm{kcal} / \mathrm{kg}$ gar can be sold at a price below the benchmark prices for coal with a conveying studies. Based on the analysis, the best alternative price is USD 19.96 per ton.

Keywords: reject coal, profit sharing, steam (thermal) coal, coal benchmark price, steam power plant mine mouth

\section{PENDAHULUAN}

\section{Latar Belakang}

Pembangkit Listrik Tenaga Uap (PLTU) Lati di Kabupaten Berau, Provinsi Kalimantan Timur, merupakan pembangkit listrik mulut tambang berbahan bakar batubara. Kehadirannya sangat penting untuk memenuhi kebutuhan listrik masyarakat dan juga untuk kebutuhan listrik perusahaan batubara PT Berau Coal.

Dengan pertimbangan pembangunan daerah, sejak 2003 PT Berau Coal menjual batubara berupa reject coal kepada PLTU Mulut Tambang Lati di kabupaten ini berdasarkan kajian Puslitbang tekMIRA (Badan Pemeriksaan Keuangan Republik Indonesia, 2008), yaitu senilai USD 0,85 per ton atau senilai bagian pemerintah (USD $6,28 \times 13,5 \%$ ). Kebijakan perusahaan tambang tersebut dapat dipandang turut menggerakkan perekonomian daerah (Suseno, 2013; Prasodjo dkk., 2015). Sementara itu, abu batubara hasil pembakaran PLTU masih mengandung unsur-unsur kimia yang berguna untuk menunjang pertumbuhan tanaman dalam kegiatan revegetasi lahan bekas tambang batubara (Kurniawan dan Hadijah, 2012; Kurniawan, 2014; Kurniawan, Surono dan Alimano, 2014). Seiring berjalannya waktu, reject coal perusahaan tersebut semakin menipis dan penggunaannya berkendala pada boiler, sehingga untuk memenuhi kebutuhan PLTU Mulut Tambang Lati dipakai batubara produk pasar. Kendala pada boiler tersebut sejalan dengan penelitian Umar dan Hudaya (2016), Umar, Sulistyohadi and Hudaya (2015), bahwa reject coal atau batubara kotor mempunyai karakteristik kandungan sulfur yang tinggi, karena itu dapat terjadi slagging pada boiler. Setelah dipakai batubara produk pasar, timbul persoalan, karena batubara perusahaan tambang tersebut termasuk batubara untuk steam (thermal) coal yang harga jualnya wajib mengikuti Harga Patokan Batubara (HPB), dikurangi biaya penyesuaian yang disetujui oleh Direktur Jenderal Mineral dan Batubara atas nama Menteri Energi dan Sumber Daya Mineral. Persoalan ini menjadi kendala dalam harga jual beli periode 2012-2015.

Sementara itu, berdasarkan hasil perhitungan HPB dan Harga Dasar Batubara (HDB) sesuai Peraturan Menteri Energi dan Sumber Daya Mineral Republik Indonesia Nomor 17 Tahun 2010 dan Peraturan Direktur Jenderal Mineral dan Batubara Nomor 515.K/32/DJB/2011 didapat harga yang tidak ekonomis bagi pihak PLTU Mulut Tambang Lati (PT IPB) maupun PT PLN. Sedangkan dari hasil perhitungan simulasi cash flow PT IPB, dengan harga batubara senilai bagian pemerintah, diperoleh harga batubara ekonomis. Namun, hal ini tidak sesuai lagi dengan peraturan yang dikeluarkan oleh Kementerian Energi dan Sumber Daya Mineral cq Direktorat Jenderal Mineral dan Batubara.

Untuk mencari win-win solution terhadap persoalan tersebut, maka dalam analisis penentuan harga jual batubara PT Berau Coal untuk PLTU Mulut Tambang Lati ini didasarkan kepada Pasal 2 dan 3 Peraturan Direktur Jenderal Mineral dan Batubara Nomor 1348.K/30/DJB/2011, bahwa harga batubara untuk pembangkit listrik mulut tambang dengan kalori lebih besar atau sama dengan $3.000 \mathrm{kkal} / \mathrm{kg}$ (gar) dapat dijual pada harga di bawah HPB dengan menyampaikan kajian. Tujuan analisis ini adalah mencari 
formula yang tepat (win-win solution) dalam menentukan harga jual batubara PT Berau Coal periode 2012-2015 yang dapat dijadikan pedoman dalam kompromi penetapan harga batubara jual beli batubara antara PT Berau Coal dan PT IPB.

\section{Dasar Hukum}

Dalam analisis penentuan harga jual batubara PT Berau Coal untuk PLTU Mulut Tambang Lati di Kabupaten Berau, Kalimantan Timur ini didasarkan kepada beberapa peraturan yang dikeluarkan oleh Kementerian Energi dan Sumber Daya Mineral cq Direktorat Jenderal Mineral dan Batubara, yaitu:

1. Peraturan Menteri Energi dan Sumber Daya Mineral Republik Indonesia Nomor 17 Tahun 2010, tentang Tata Cara Penetapan Harga Patokan Penjualan Mineral dan Batubara.

Pasal 11 ayat (1): Direktur Jenderal atas nama Menteri menetapkan harga patokan batubara untuk steam (thermal) coal dan coking (metallurgical) coal sebagaimana dimaksud dalam Pasal 10 setiap bulan berdasarkan formula yang mengacu pada rata-rata indeks harga batubara sesuai dengan mekanisme pasar dan/atau sesuai dengan harga yang berlaku umum di pasar internasional.

Pasal 13 ayat (2): Pemegang IUP Operasi Produksi batubara dan IUPK Operasi Produksi batubara dalam menghitung harga penjualan batubara sebagaimana dimaksud dalam Pasal 12 ayat (2) huruf b, huruf $c$, dan huruf $d$ wajib mengikuti harga patokan batubara dan ditambah atau dikurangi biaya penyesuaian yang disetujui oleh Direktur Jenderal atas nama Menteri.

2. Peraturan Direktur Jenderal Mineral dan Batubara Nomor 515.K/32/DJB/2011, tentang Formula Untuk Penetapan Harga Patokan Batubara.

Pasal 3 ayat (1): Formula untuk penetapan harga patokan batubara steam (thermal) sebagaimana dimaksud dalam Pasal 2 ayat (1) merupakan acuan dalam menghitung harga patokan batubara steam (thermal) untuk jenis batubara utama dan batubara lainnya.

Pasal 3 ayat (6): Formula harga patokan batubara steam (thermal) untuk jenis batubara utama dan jenis batubara lainnya dan/atau berdasarkan nama dagang (brand) ditetapkan sebagaimana tercantum dalam Lampiran I dan Lampiran II Peraturan Direktur Jenderal ini.

3. Peraturan Direktur Jenderal Mineral dan Batubara Nomor 644.K/30/DJB/2013, tentang Perubahan Atas Peraturan Direktur Jenderal Mineral dan Batubara Nomor 999.K/30/DJB/2011 tentang Tata Cara Penetapan Besaran Biaya Penyesuaian Harga Patokan Batubara.

Pasal 6 ayat (2): Penetapan besaran biaya penyesuaian untuk perhitungan pengurangan HPB penjualan batubara dalam satu pulau sampai pengguna akhir sebagaimana dimaksud dalam Pasat 4 ayat (2) sebagaimana tercantum dalam Lampiran II yang merupakan bagian tidak terpisahkan dari Peraturan Direktur Jenderal ini.

4. Peraturan Direktur Jenderal Mineral dan Batubara Nomor 1348.K/30/DJB/2011 tentang Penentuan Harga Batubara untuk Pembangkit Listrik Mulut Tambang.

Pasal 3 ayat (1): Harga batubara untuk pembangkit listrik mulut tambang dengan kalori lebih besar atau sama dengan 3.000 $\mathrm{kkal} / \mathrm{kg}$ (gar) dapat dijual dengan harga di bawah Harga Patokan Batubara yang disetujui oleh Direktur Jenderal berdasarkan kajian yang akan ditetapkan dalam Keputusan Direktur Jenderal.

\section{METODE}

\section{Metode Inventarisasi/Pengumpulan dan Pengolahan Data}

Metodologi yang digunakan dalam analisis ini adalah penggabungan antara metode penelitian survei dan desk work dengan menerapkan beberapa metode analisis statistik. Penelitian survei dilakukan untuk inventarisasi/pengumpulan data dengan teknik 
observasi dan wawancara berpanduan (interview guide) ke PT Berau Coal, PT IPB dan PT PLN Wilayah Berau. Sedangkan beberapa metode analisis statistik yang digunakan dalam pengolahan dan analisis data adalah pendekatan statistika deskriptif dan model analisis regresi linier.

Statistika deskriptif adalah metode statistika yang digunakan untuk analisis data dengan cara mendeskripsikan atau menggambarkan data yang telah terkumpul sebagaimana adanya tanpa ada tujuan membuat kesimpulan untuk generalisasi. Informasi yang dapat diperoleh dari statistika deskriptif ini antara lain ukuran pemusatan data, ukuran penyebaran data dan kecenderungan suatu gugus data yang disajikan dalam grafik atau tabel.

Analisis regresi linier sederhana adalah hubungan secara linear antara satu variabel independen $(X)$ dengan variabel dependen (Y). Analisis ini untuk mengetahui arah hubungan antara variabel independen dengan variabel dependen, apakah positif atau negatif dan untuk memprediksi nilai dari variabel dependen apabila nilai variabel independen mengalami kenaikan atau penurunan. Data yang digunakan biasanya berskala interval atau rasio.

Rumus regresi linear sederhana sebagai berikut:

$\mathrm{Y}=\mathrm{a}+\mathrm{bX}$

Keterangan:

$\mathrm{Y}=$ Variabel dependen (nilai yang diprediksikan)

$\mathrm{X}=$ Variabel independen

$\mathrm{a}=$ Konstanta regresi

$\mathrm{b}=$ Koefisien regresi (nilai peningkatan ataupun penurunan)

Untuk melengkapi analisis regresi diperlukan perhitungan koefisien penentu atau koefisien determinasi $\left(R^{2}\right)$. Koefisien determinasi ini menjelaskan besarnya pengaruh nilai suatu variabel (variabel X) terhadap naik/turunnya (variasi) nilai variabel lainnya (variabel Y).

Model koefisiensi determinasi:

$R^{2}=\frac{\left[(n)\left(\sum X Y\right)-\left(\sum X\right)\left(\sum Y\right)\right]^{2}}{\left[n\left(\sum X^{2}\right)-\left(\sum X\right)^{2}\right]\left[n\left(\sum Y^{2}\right)-\left(\sum Y\right)^{2}\right]}$
Untuk memudahkan pengolahan dan analisis data, digunakan Program Excell atau Program Statistical Package for the Social Sciences (SPSS).

\section{Metode Analisis Data}

Sesuai dengan tujuan analisis ini, yaitu menentukan harga jual batubara PT Berau Coal untuk PLTU Mulut Tambang Lati di Kabupaten Berau, maka terlebih dahulu harus diketahui biaya penyediaan batubara dan sistem kontrak penambangannya. Untuk mengetahui hal tersebut digunakan beberapa metode analisis, yaitu:

1. Analisis biaya penyediaan batubara, termasuk di dalamnya adalah biaya penambangan, biaya pengolahan, biaya transportasi, serta biaya-biaya lain yang terkait.

2. Analisis sistem kontrak penambangan yang berlaku yang di antaranya mengatur cara pembayaran nilai bagian pemerintah.

Sedangkan untuk menghitung kelayakan harga jual batubara dianalisis berdasarkan:

1. Sisi produsen, yaitu harga batubara harus mencerminkan biaya penyediaannya (harga merupakan biaya ditambah keuntungan).

2. Sisi konsumen, yaitu harga batubara harus setara dengan harga barang penggantinya (substitusinya).

3. Kajian harga jual batubara berdasarkan nilai profitabilitasnya, yaitu melihat kelayakan harga dari kelayakan usaha penambangan batubara.

\section{HASIL DAN PEMBAHASAN}

PLTU Lati merupakan PLTU mulut tambang dan keberadaannya terkait dengan adanya perusahaan batubara PT Berau Coal. Kondisi ini sejalan dengan pendapat (Suseno, 2013, 2017) bahwa PLTU skala kecil yang akan dibangun sebaiknya disesuaikan dengan karakteristik batubara dari pemasok, dan PLTU tersebut berbahan bakar batubara, sebagai solusi menghindari penggunaan 
energi minyak bumi (BBM) yang harganya semakin tinggi. Awalnya, PLTU Lati menggunakan bahan bakar reject coal. PLTU Lati berkembang sejalan dengan permintaan konsumen. Dalam perjalanannya, batubara yang digunakan tidak lagi menggunakan reject coal, karena tidak cocok dengan boilernya, tetapi sudah menggunakan batubara non reject coal seperti yang dijual di pasaran oleh PT Berau Coal. Permasalahan yang timbul sejak adanya kebijakan HPB, maka harga jual batubara tersebut harus mengikuti peraturan yang ada. Untuk periode 2012-2015, harga batubara belum ada kesepakatan, padahal penggunaan batubara tersebut oleh PLTU Lati sudah berjalan, sehingga perlu dicarikan solusi untuk memecahkan masalah tersebut. Kondisi tersebut tidak mengganggu PT Berau Coal sebagai kontraktor yang mempunyai kewajiban keuangan dan wajib membayar secara langsung berdasarkan ketentuan yang berlaku mengenai $13,5 \%$ hasil produksinya kepada prinsipal (Yunianto, 2015).

\section{Harga Batubara PT Berau Coal untuk PLTU Lati}

Bagi para pihak yang ingin melakukan jualbeli batubara dan akan menentukan harga batubara harus mengacu kepada Peraturan Menteri Energi dan Sumber Daya Mineral (Permen ESDM) Nomor 17 Tahun 2010 tentang Tata Cara Penetapan Harga Patokan Penjualan Mineral dan Batubara (Menteri Energi dan Sumber Daya Mineral, 2010). Harga batubara ditentukan oleh ESDM yang berlaku untuk jangka waktu tertentu dan ditetapkan berdasarkan Perdirjen Minerba. Di samping acuan untuk jual beli batubara, Harga Patokan Batubara (HPB) ini adalah harga batubara terendah untuk menentukan besarnya jumlah royalti yang harus dibayarkan perusahaan batubara. Demikian halnya harga jual beli batubara antara PT Berau Coal dan PT IPB harus mengacu pada ketetapan Direktur Jenderal Mineral dan Batubara.

Formula penetapan HPB tersebut diatur dalam Peraturan Direktur Jenderal Mineral dan Batubara (Perdirjen Minerba) Nomor 515.K/32/DJB/2011 (Direktorat Jenderal Mineral dan Batubara, 2011). Menimbang bahwa PLTU Lati merupakan PLTU Mulut Tambang, maka berlaku ketentuan biaya penyesuaian yang diatur dalam Perdirjen
Minerba Nomor 664.K/30/DJB/2013, penjualan batubara dalam satu pulau sampai dengan pengguna akhir wajib mengikuti HPB dan dikurangi biaya penyesuaian (Direktorat Jenderal Mineral dan Batubara, 2011, 2013). Berdasarkan perhitungan dengan menggunakan acuan yang diatur dalam Perdirjen Minerba tersebut dapat diketahui untuk periode 2012-2015, HPB PT Berau Coal untuk PLTU Lati sebagaimana disajikan pada Tabel 1.

Di samping itu, ada alternatif lain terkait dengan jual beli batubara batubara PT Berau Coal dengan PT IPB, yaitu merujuk pada Permen ESDM No 10 Tahun 2014 dan telah diperbaharui oleh Permen ESDM No 09 Tahun 2016, tentang Tata Cara Penyediaan dan Penetapan Harga Batubara Untuk Pembangkit Listrik Mulut Tambang (Menteri Energi dan Sumber Daya Mineral, 2016). Penetapan harga batubara untuk PLTU Mulut Tambang dihitung berdasarkan Harga Dasar Batubara, yang diatur oleh Perdirjen Minerba Nomor 953.K/32/DJB/2015, yang formulanya adalah biaya produksi ditambah margin. Hitungan harga batubara untuk PLTU Lati berdasarkan formula dimaksud tersebut, disajikan pada Tabel 2 .

Dari dua alternatif perhitungan harga batubara PT Berau Coal untuk PLTU mulut tambang Lati, diketahui bahwa untuk dua tahun terakhir (2014-2015) berdasarkan acuan HPB lebih rendah dibandingkan berdasarkan acuan HDB, namun dua tahun sebelumnya kondisinya terbalik. Hal ini disebabkan harga pasar batubara selama 4 tahun terakhir (20122015) turun secara signifikan, tetapi biaya produksi relatif tetap.

\section{Produksi dan Penjualan Listrik PLTU Lati (PT IPB)}

PT IPB adalah perusahaan yang mengoperasikan pembangkit listrik tenaga uap berbahan bakar batubara berkapasitas 3x7 MW di Kabupaten Berau-Kalimantan Timur. Energi listrik yang diproduksi oleh PLTU Lati, disalurkan kepada 2 konsumennya, yaitu PT PLN (Persero) Wilayah Kalimantan Timur, Cabang Berau, dan PT Berau Coal salah satu perusahaan pertambangan batubara yang ada di Kabupaten Berau. 
Produksi listrik sejak 2012 terus meningkat sampai dengan akhir 2016 yang direncanakan sebesar 151.341 MWh. Rata-rata pertumbuhan per tahun sekitar 10,83\% (Tabel 3). Peningkatan ini terutama disebabkan oleh kemampuan perusahaan dalam memaksimalkan kapasitas produksi energi listrik. Penyaluran energi listrik pada 2016 direncanakan sebesar $124.513 \mathrm{MWh}$, meningkat dibandingkan tahun-tahun sebelumnya. Berdasarkan data 2012-2016 pertumbuhan penjualan listrik per tahun sekitar $11,55 \%$. Komposisi penyaluran energi listrik ke PT PLN (Persero) dan ke PT Berau Coal rata-rata adalah $97,38 \%$ dan $2,62 \%$.

\section{Biaya Operasi dan Harga Jual Listrik PT IPB}

Sejak awal beroperasi hingga saat ini PT IPB dalam mengoperasikan PLTU Lati memanfaatkan bahan bakar batubara dari PT Berau Coal. Berdasarkan perjanjian awal harga batubara PT Berau Coal dihargakan sebesar nilai bagi hasil bagian pemerintah atau royalti $(13,5 \%)$ dari harga batubara tersebut. Pada kenyataannya, harga batubara ini adalah harga coal getting, sehingga harga di bawah harga pasar atau harga jual patokan batubara (HPB). Hal tersebut dapat ditelusuri dari data perkembangan harga jual listrik PT IPB seperti pada Tabel 4. Berdasarkan informasi, baik dari PT Berau Coal maupun PT IPB, batubara untuk PLTU Lati dihargakan USD 2,41 dan sebelumnya USD 2,1 per ton.

Dari tabel cash flow tersebut, harga pokok produksi PLTU Lati untuk tahun 2015 ini sebesar Rp. 646,44/kWh, dengan komponen biaya royalti batubara Rp. 37,59/kWh. Dengan mengambil keuntungan 15\%, harga jual energi listrik sebesar Rp 743,41/kWh. Dari 2012 hingga 2014, harga-harga tersebut mengalami peningkatan, sedangkan pada 2015 ada penurunan dibanding tahun 2014.

Tabel 1. Harga patokan batubara PT Berau Coal untuk PLTU Lati

\begin{tabular}{|c|c|c|c|c|c|}
\hline PARAMETER & TAHUN & 2012 & 2013 & 2014 & 2015 \\
\hline & & \multicolumn{4}{|c|}{ Envirocoal } \\
\hline Nilai Kalor (i) & (Gar) & 5.000 & 5.000 & 5.000 & 5.000 \\
\hline Kandungan Air (i) & $(\%)$ & 26,00 & 26,00 & 26,00 & 26,00 \\
\hline Kandungan Belerang (i) & $(\%)$ & 0,10 & 0,10 & 0,10 & 0,10 \\
\hline Kandungan Abu Batubara (i) & $(\%)$ & 1,20 & 1,20 & 1,20 & 1,20 \\
\hline \multirow[t]{2}{*}{ HPB envirocoal (i) } & (USD/ton) & 70,25 & 61,15 & 55,06 & 49,98 \\
\hline & & \multicolumn{4}{|c|}{ Batubara Lati PT Berau Coal } \\
\hline Nilai Kalor (j) & (Gar) & 5.203 & 5.039 & 4.957 & 5.129 \\
\hline Kandungan Air (i) & $(\%)$ & 23,57 & 24,73 & 25,06 & 23,83 \\
\hline Kandungan Belerang (j) & $(\%)$ & 1,47 & 1,39 & 1,28 & 1,38 \\
\hline Kandungan Abu Batubara (j) & $(\%)$ & 4,85 & 5,33 & 5,85 & 4,91 \\
\hline HPB Berau Coal (j) & (USD/ton) & 67,87 & 55,64 & 48,68 & 42,60 \\
\hline \multicolumn{6}{|l|}{ Biaya Penyesuaian : } \\
\hline Bongkar muat & (USD/ton) & 2,05 & 2,05 & 2,37 & 2,52 \\
\hline Sewa peralatan dan bahan bakar pengiriman & (USD/ton) & 0,45 & 0,45 & 0,41 & 0,31 \\
\hline Tongkang batubara & (USD/ton) & 0,00 & 0,00 & 0,00 & 0,00 \\
\hline Penimbunan dan Pemuatan Batubara & (USD/ton) & 0,58 & 0,59 & 0,54 & 0,53 \\
\hline Perawatan Batubara & (USD/ton) & 0,01 & 0,00 & 0,00 & 0,00 \\
\hline Penghancuran Batubara & (USD/ton) & 0,35 & 0,02 & 0,00 & 0,00 \\
\hline Biaya Pengangkutan Batubara & (USD/ton) & 0,87 & 0,89 & 0,92 & 0,98 \\
\hline Jumlah Biaya Penyesuaian & (USD/ton) & 4,31 & 3,997 & 4,24 & 4,35 \\
\hline HPB Berau Coal (j) untuk PLTU Lati (term) & (USD/ton) & 63,56 & 51,65 & 44,44 & 38,26 \\
\hline
\end{tabular}

Sumber : PT Berau Coal (2016a, 2016b, 2016c, 2016d, 2016e diolah kembali)

Catatan :

HPB Berau Coal $(\mathrm{j})=(($ HPB envirocoal $(\mathrm{i})+(($ Kandungan Belerang $(\mathrm{i})-0,8) * 4)+(($ Kandungan Abu Batubara (i) -

$15) * 0,4)) *(\mathrm{~K}(\mathrm{j}) / \mathrm{K}(\mathrm{i})) *((100-\mathrm{Kandungan} \mathrm{Air}(\mathrm{j})) /(100-\mathrm{Kandungan} \mathrm{Air}(\mathrm{i}))) *((100-8) /(100-8)))$ -

$(($ Kandungan Belerang $\left.\left.(\mathrm{j})-0,8) * 4)+\left((\text { Kandungan Abu Batubara }(\mathrm{j})-15)^{*} 0,4\right)\right)\right)$ 
Tabel 2. Harga dasar batubara PT Berau Coal untuk PLTU Lati

\begin{tabular}{|c|c|c|c|c|c|c|c|}
\hline & Jenis Biaya & Satuan & 2011 & 2012 & 2013 & 2014 & 2015 \\
\hline $\mathrm{a}$ & $\begin{array}{l}\text { Pengupasan } \mathrm{OB} \\
\text { Pengangkutan } \mathrm{OB}\end{array}$ & USD/ton & 19,16 & 21,22 & 27,19 & 22,57 & 21,73 \\
\hline $\mathrm{b}$ & Penggalian Batubara & USD/ton & 1,79 & 0,58 & 0,59 & 0,53 & 0,53 \\
\hline C & Pengangkutan Batubara (Pit ke Stockpile) & USD/ton & 7,89 & 7,58 & 8,88 & 9,24 & 9,87 \\
\hline$d$ & Pengangkutan Batubara (Stockpile ke PLTU) & USD/ton & & N/A & N/A & N/A & $\mathrm{N} / \mathrm{A}$ \\
\hline $\mathrm{e}$ & Pengolahan Batubara & USD/Ton & 0,86 & 0,86 & 0,86 & 0,60 & 0,55 \\
\hline$f$ & Pemantauan \& pengelolaan lingkungan & & & & & & \\
\hline $\begin{array}{l}\mathrm{g} \\
\mathrm{h}\end{array}$ & $\begin{array}{l}\text { Reklamasi \& pasca tambang } \\
\text { K3 }\end{array}$ & USD/Ton & 0,23 & 0,23 & 0,23 & 0,18 & 0,18 \\
\hline i & Pengembangan\&pemberdayaan masyarakat (CSR) & USD/Ton & 0,26 & 0,26 & 0,26 & 0,31 & 0,34 \\
\hline j & Pembebasan/penggantian tanah & USD/Ton & N/A & N/A & N/A & N/A & N/A \\
\hline k & Biaya Tambahan & USD/Ton & 1,77 & 1,77 & 1,77 & 1,17 & 1,15 \\
\hline I & Depresiasi dan amortisasi & USD/Ton & $\mathrm{N} / \mathrm{A}$ & N/A & $\mathrm{N} / \mathrm{A}$ & $\mathrm{N} / \mathrm{A}$ & $\mathrm{N} / \mathrm{A}$ \\
\hline $\mathrm{m}$ & Iuran Tetap & USD/Ton & & & \multicolumn{3}{|c|}{ termasuk biaya CSR } \\
\hline & Royalti & USD/Ton & 6,49 & 6,60 & 8,07 & 7,02 & 6,97 \\
\hline \multicolumn{2}{|c|}{ Biaya Produksi } & USD/Ton & 38,45 & 39,10 & 47,85 & 41,62 & 41,32 \\
\hline \multicolumn{8}{|c|}{ Keuntungan Kotor: } \\
\hline $\mathrm{a}$ & Keuntungan Kotor (15\%) & USD/Ton & 5,77 & 5,87 & 7,18 & 6,24 & 6,20 \\
\hline $\mathrm{b}$ & Keuntungan Kotor (25\%) & USD/Ton & 9,61 & 9,78 & 11,96 & 10,41 & 10,33 \\
\hline \multicolumn{8}{|c|}{ Harga Dasar Batubara : } \\
\hline $\mathrm{a}$ & $\begin{array}{l}\text { Harga Dasar Batubara (dengan Keuntungan Kotor } \\
15 \%)\end{array}$ & USD/Ton & 44,22 & 44,97 & 55,03 & 47,86 & 47,52 \\
\hline b & $\begin{array}{l}\text { Harga Dasar Batubara (dengan Keuntungan Kotor } \\
25 \% \text { ) }\end{array}$ & USD/Ton & 48,06 & 48,88 & 59,82 & 52,03 & 51,66 \\
\hline
\end{tabular}

Sumber : PT Berau Coal (2016a, 2016b, 2016c, 2016d, 2016e diolah kembali)

Tabel 3. Produksi dan penyaluran energi listrik (2012-2016)

\begin{tabular}{lrrrrrr}
\hline \multicolumn{1}{c}{ Tahun } & 2012 & 2013 & 2014 & 2015 & 2016 & $\begin{array}{c}\text { Rata-Rata } \\
\text { Pertumbuhan } \\
(\%)\end{array}$ \\
\hline Jumlah Produksi Energi Listrik & 100.921 & 108.696 & 116.710 & 141.977 & 151.341 & 10,83 \\
Penyaluran Energi Listrik (KWh) & 80.823 & 89.639 & 97.000 & 117.825 & 124.513 & 11,55 \\
Penjualan Ke PT PLN (KWh) & 77.713 & 87.786 & 96.415 & 114.615 & 120.012 & 11,59 \\
Penjualan Ke PT BC (KWh) & 3.169 & 1.853 & 585 & 3.210 & 4.501 & 94,78 \\
Pemakaian Batubara (ton) & 102.234 & 109.580 & 117.865 & 135.477 & 77.271 & 9,90 \\
\hline
\end{tabular}

Sumber : PT Indo Pusaka Berau (2016a, 2016b, 2016c, 2016d, 2016e diolah kembali)

\section{Simulasi Harga Jual Listrik PT IPB berdasarkan Alternatif Harga Batubara}

Pada awalnya, PLTU Lati menggunakan batubara kualitas rendah yang merupakan bagian dari proses pengupasan tanah penutup, sehingga harga batubara berdasarkan biaya coal getting. Namun pada perjalanannya, batubara yang dipasok ke PLTU Lati sudah berubah tidak lagi menggunakan reject coal, tetapi sudah dikategorikan batubara yang dipasarkan secara komersial pada umumnya.
Kondisi ini sejalan dengan hasil kajian Saefudin dan Supriyantono (2012) bahwa nilai keekonomian batubara jenis reject coal belum ekonomis, karena akan kalah bersaing dengan produk batubara hasil penambangan yang nilai kalornya hampir sama dan kandungan abu lebih rendah. Oleh karena itu, dalam kajian harga batubara PT Berau Coal untuk PLTU Lati 2012-2015, akan dilakukan dengan 3 pendekatan simulasi perhitungan, yaitu: skenario royalti, skenario HPB, dan skenario HDB. 


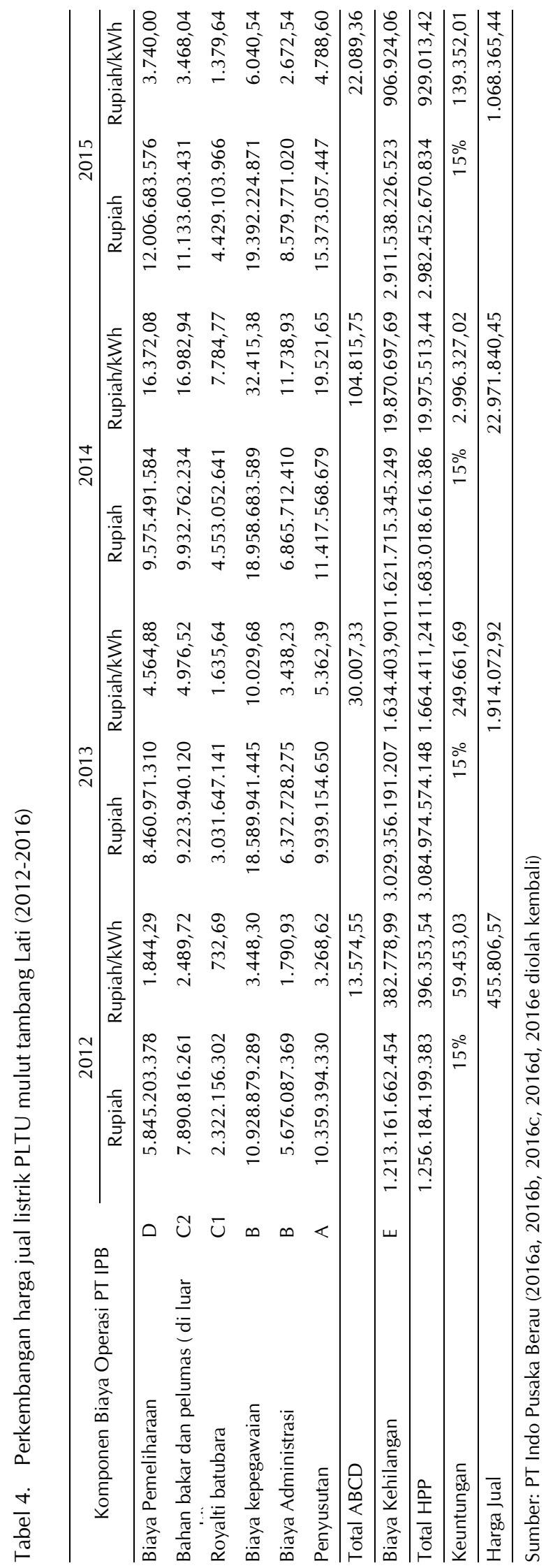




\section{Harga Jual Listrik Berdasarkan Harga Batubara $=$ Royalti}

Simulasi pertama menghitung biaya produksi atau harga jual listrik, adalah skenario harga jual batubara PT Berau Coal untuk PLTU Lati, yaitu harga royalti dari HPB seperti telah diutarakan di atas. Dengan demikian, apabila nilai royalti batubara dijadikan sebagai harga jual batubara, sebagai pengganti komponen royalti (biaya bahan bakar batubara) dari harga coal getting (diasumsikan USD 2,41) dalam Tabel 4, maka gambarannya seperti pada Tabel 5 dan Gambar 1. Komponen biaya bahan bakar batubara telah berubah, misalnya untuk tahun 2015 yang semula Rp. 37,59/kwh menjadi Rp. 80,86/kwh (USD 2,41/ton menjadi USD 5,17/ton), maka harga jual listrik berubah dari Rp. 743,41 menjadi Rp. 796,86. Dengan perkataan lain apabila harga bahan bakar batubara dinaikkan sebesar 53,47\% akan berpengaruh menaikkan harga jual listrik $6,71 \%$.

\section{Harga Jual Listrik Berdasarkan Harga Batubara $=$ HPB}

Seperti telah disebutkan di atas, ada Permen ESDM No. 17 Tahun 2010 dan Perdirjen Minerba No. 515.K/32/DJB/2011, terkait dengan kebijakan pengaturan harga patokan penjualan batubara. Apabila HPB ini dijadikan sebagai harga jual batubara, sebagai pengganti komponen royalti dari harga coal getting, maka terjadi perubahan komponen biaya yang cukup signifikan. Untuk 2015, dengan kenaikan harga bahan bakar batubara dari Rp. 37,59/kwh menjadi Rp. 598,95/kwh (USD 2,41/ton menjadi USD 38,26/ton), harga jual listrik berubah dari Rp. 743,41 menjadi Rp. 1.436,80. Gambaran selama 2012-2015 dapat dilihat seperti pada Tabel 6 dan Gambar 2 .

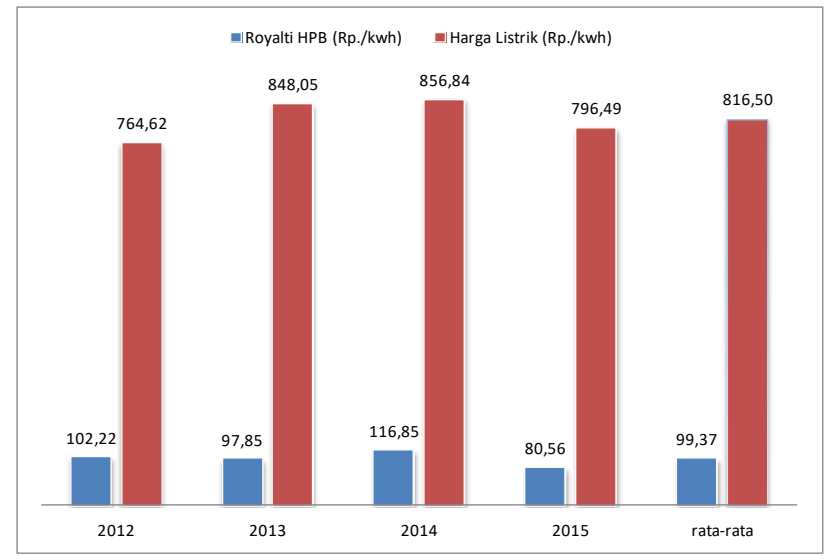

Gambar 1. Biaya royalti batubara dan harga jual listrik (2012-2015)

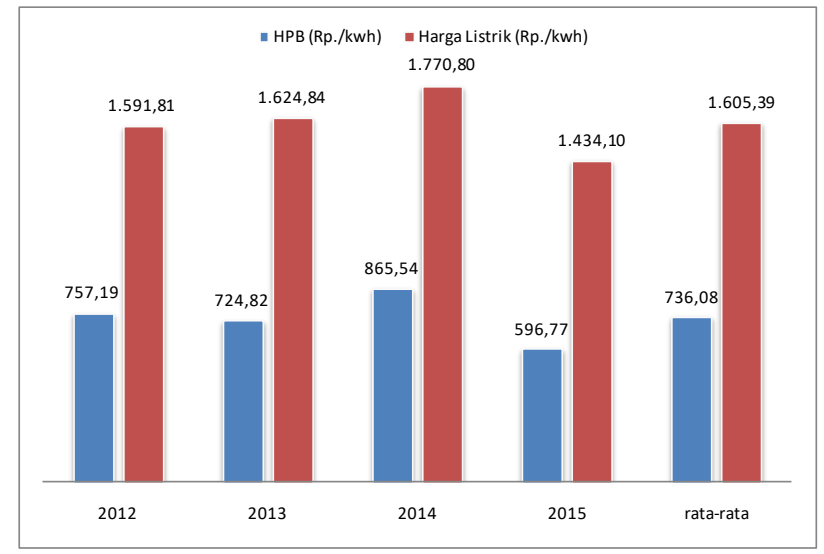

Gambar 2. Biaya HPB dan Harga Jual Listrik (2012-2015) 

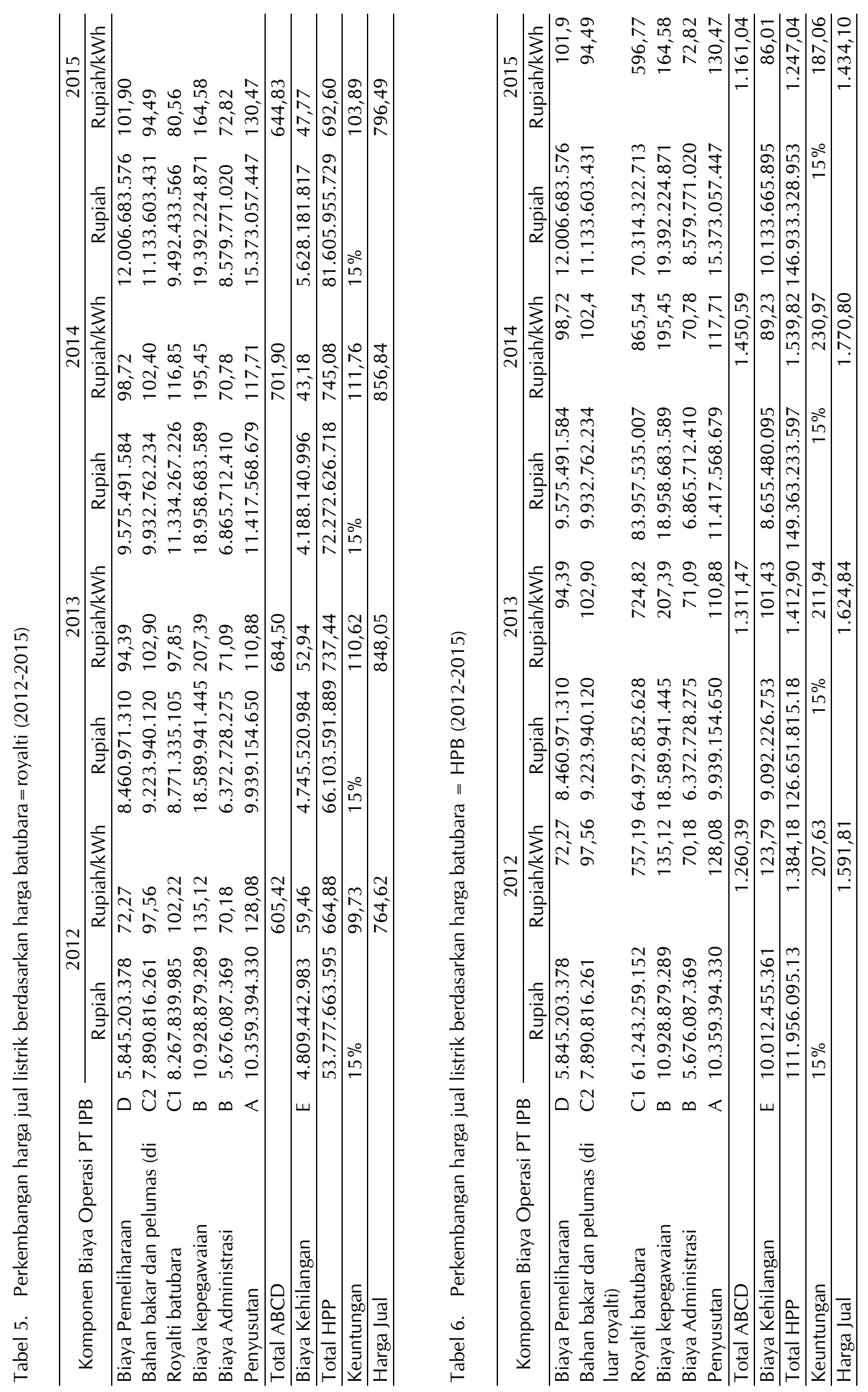


\section{Harga Jual Listrik Berdasarkan Harga Batubara $=$ HDB}

Skenario ketiga untuk simulasi harga jual listrik PT IPB adalah menggunakan komponen harga bahan batubara batubara mengacu pada HDB yang diatur oleh Perdirjen Minerba Nomor 953.K/32/DJB/ 2015, yang formulanya adalah biaya produksi batubara ditambah margin. Apabila HDB ini dijadikan sebagai harga jual batubara, sebagai pengganti komponen royalti dari harga coal getting dalam Tabel 4, maka gambarannya seperti pada Tabel 7 dan Gambar 3. Untuk 2015, dengan kenaikan harga bahan bakar batubara dari Rp. 37,59/kwh menjadi Rp. $741,39 /$ kwh (USD 2,41/ton menjadi USD 47,52/ton), harga jual listrik berubah dari Rp. 743,41/kwh menjadi Rp. 1.612,74/kwh. Dengan demikian, apabila harga bahan bakar batubara dinaikkan sebesar 94,93\% akan berpengaruh menaikkan harga jual listrik $53,90 \%$.

\section{Analisis Harga Batubara PT Berau Coal Untuk PLTU Lati}

\section{Hubungan Harga Batubara, Harga Listrik PT IPB dan PT PLN}

Dari hasil simulasi perubahan harga jual listrik PT IPB atas dasar biaya bahan bakar batubara senilai royalti coal getting menjadi 3 skenario perhitungan (royalti HPB, HPB, dan HDB), dapat digambarkan untuk rata-rata tahun 2012-2015 secara bersamaan seperti ditunjukkan pada Gambar 4. Pada gambar tersebut dimasukkan garis harga jual listrik PT PLN (asumsi/perkiraan).

Ketika biaya bahan bakar batubara seharga rata-rata royalti HPB, rata-rata harga jual listrik PT IPB adalah Rp. 816,5/kwh dan mempunyai selisih dengan harga jual listrik PT PLN (asumsi Rp. 1.300/kwh) adalah sebesar Rp. $483,50 / \mathrm{kwh}$, atau menurun $13,84 \%$ dibandingkan dengan harga listrik atas dasar harga batubara coal getting. Namun ketika harga batubara senilai HPB ataupun HDB, harga jual listrik PT IPB lebih tinggi dari harga jual listrik PT PLN (Tabel 8).

\section{Analisis Penentuan Harga Batubara}

Berdasarkan hasil simulasi terhadap cash flow PT IPB, skenario harga batubara senilai royalti HPB masih menunjukkan keekonomisan harga jual listrik PT IPB, tetapi tidak ekonomis bagi PT Berau Coal. Sedangkan berdasarkan HPB dan HDB menunjukkan ketidakekonomisan bagi PT IPB, karena melampaui harga jual listik PT PLN (asumsi Rp. 1.300/kwh).

Untuk mencari win-win solution terhadap persoalan tersebut, maka dalam menentukan harga jual batubara untuk PLTU Lati berikut ini didasarkan kepada Peraturan Direktur Jenderal Mineral dan Batubara Nomor 1348.K/30/DJB/2011, Pasal 2 dan 3, yang menyebutkan bahwa harga batubara untuk pembangkit listrik mulut tambang dengan kalori lebih besar atau sama dengan 3.000 $\mathrm{kkal} / \mathrm{kg}$ (gar) dapat dijual dengan harga di bawah HPB dengan menyampaikan kajian.

\section{Analisis Penentuan Harga Batubara}

Berdasarkan hasil simulasi terhadap cash flow PT IPB, skenario harga batubara senilai royalti HPB masih menunjukkan keekonomisan harga jual listrik PT IPB, tetapi tidak ekonomis bagi PT Berau Coal. Sedangkan berdasarkan HPB dan HDB menunjukkan ketidakekonomisan bagi PT IPB, karena melampaui harga jual listik PT PLN (asumsi Rp. 1.300/kwh).

Untuk mencari win-win solution terhadap persoalan tersebut, maka dalam menentukan harga jual batubara untuk PLTU Lati berikut ini didasarkan kepada Peraturan Direktur Jenderal Mineral dan Batubara Nomor 1348.K/30/DJB/2011, Pasal 2 dan 3, yang menyebutkan bahwa harga batubara untuk pembangkit listrik mulut tambang dengan kalori lebih besar atau sama dengan 3.000 $\mathrm{kkal} / \mathrm{kg}$ (gar) dapat dijual dengan harga di bawah HPB dengan menyampaikan kajian. 


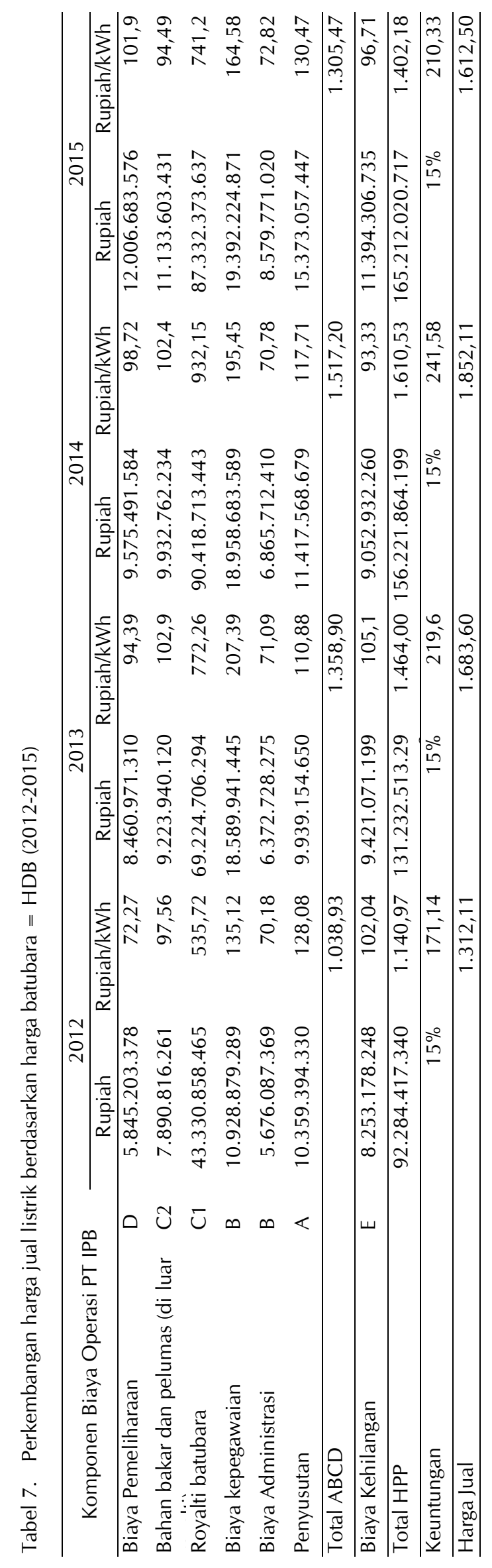




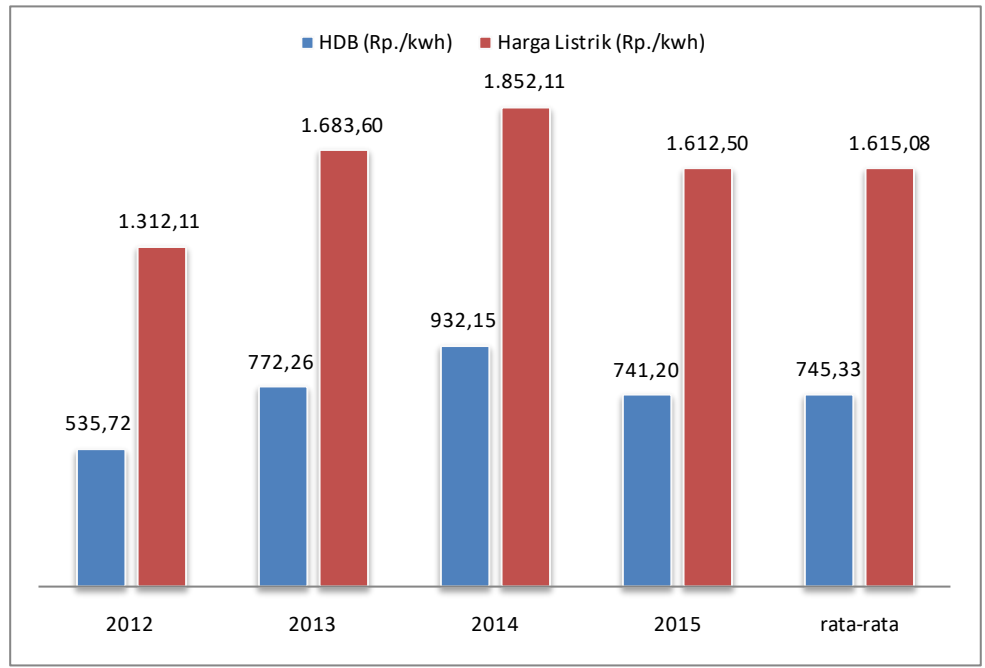

Gambar 3. Biaya HDB dan harga jual listrik (2012-2015)

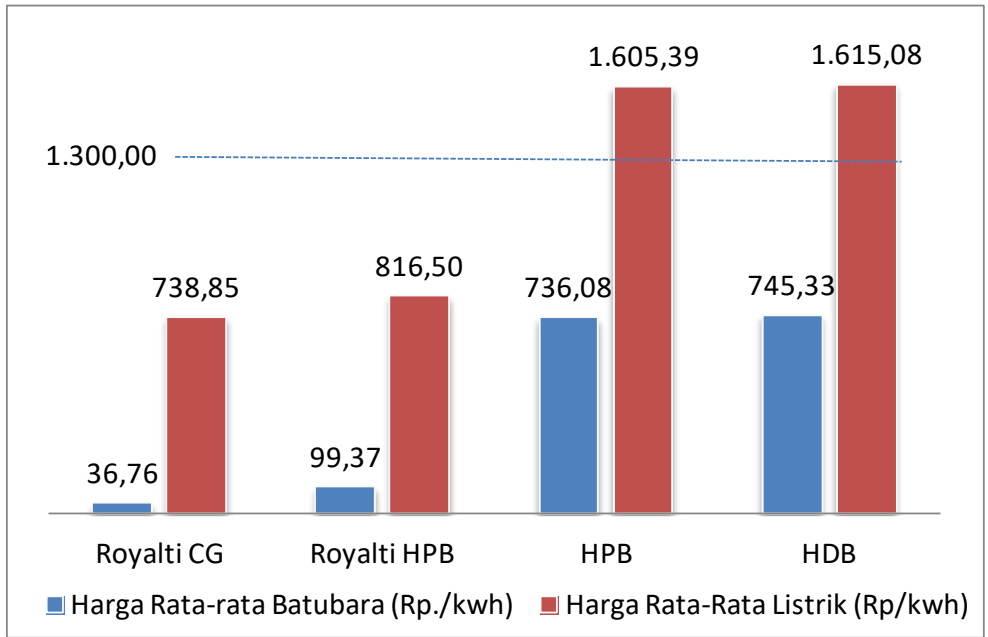

Gambar 4. Hubungan perubahan harga rata-rata batubara dan harga listrik

Tabel 8. Pengaruh perubahan rata-rata harga batubara terhadap harga listrik

\begin{tabular}{ccc}
\hline Skenario & $\begin{array}{c}\text { Selisih Harga Listrik } \\
\text { PT PLN - PT IPB (Rp./kwh) }\end{array}$ & $\begin{array}{c}\text { Penurunan } \\
(\%)\end{array}$ \\
\hline Royalti CG & 561,15 & \\
Royalti HPB & 483,50 & 13,84 \\
HPB & $-305,39$ & 154,42 \\
HDB & $-315,08$ & 156,15 \\
\hline
\end{tabular}

Kajian analisis penentuan harga batubara yang dimaksud adalah mencari suatu alternatif harga batubara PT Berau Coal di antara harga jual listrik PT IPB dan harga jual listrik PT PLN, yaitu nilai tengah dari harga jual listrik PT IPB berdasarkan royalti HPB dan asumsi harga jual listrik PT PLN (Rp. 1.058,25/kwh). Untuk itu, pendekatan model analisis adalah melalui interpolasi berdasarkan persamaan regresi. Pertama pola hubungan (regresi) antara harga jual listrik PT IPB (Rp./kwh) dengan biaya bahan bakar batubara (Rp./kwh) 
(Gambar 5). Kedua persamaan regresi antara biaya bahan bakar batubara (Rp./kwh) dan

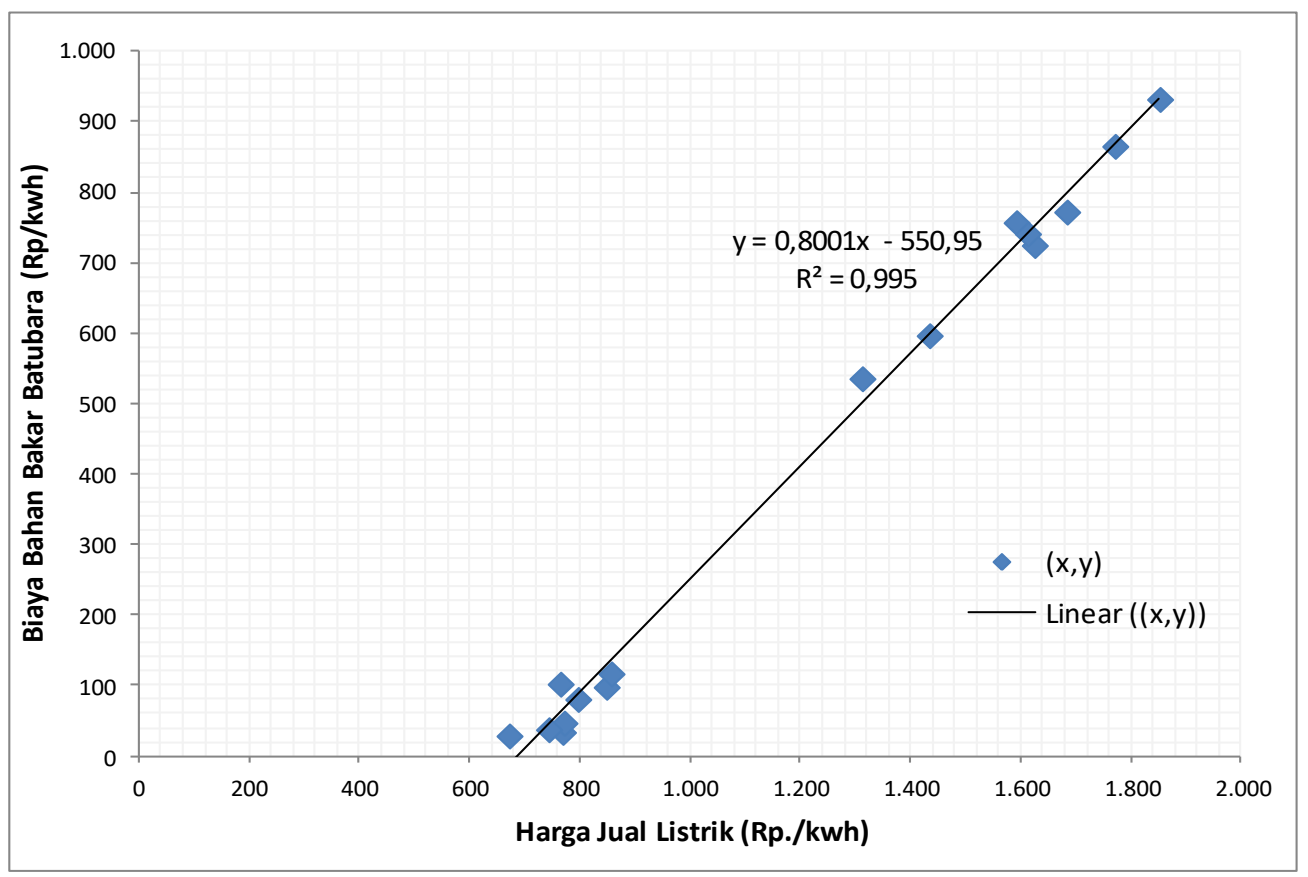

Gambar 5. Hubungan harga jual listrik dengan biaya bahan bakar batubara

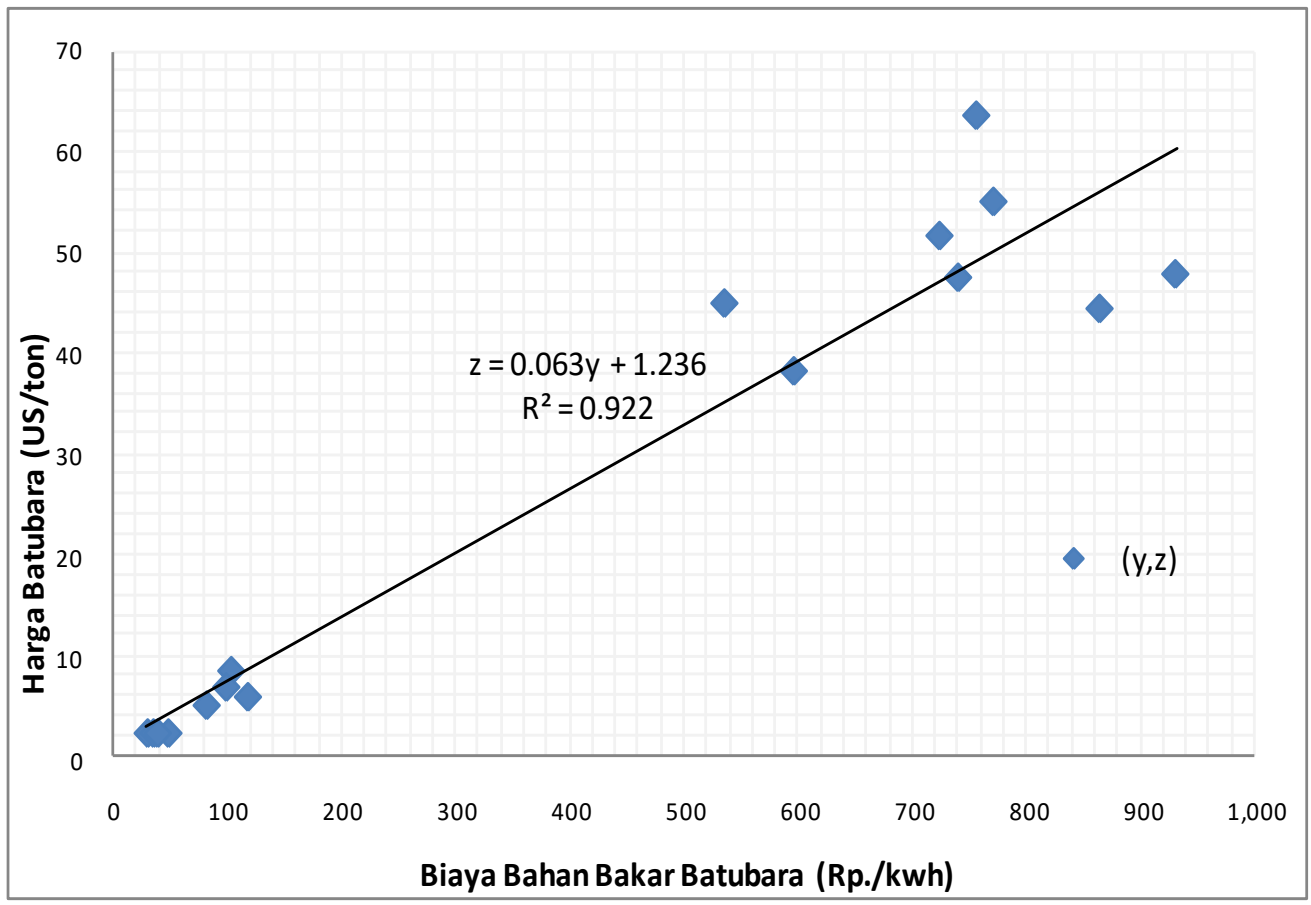

Gambar 6. Hubungan biaya bahan bakar batubara dan harga batubara 
Dari kedua pemodelan regresi diperoleh persamaan regresi dengan koefisien determinasi yang cukup kuat $\left(R^{2}>90 \%\right)$, sehingga cukup baik untuk memperkirakan harga batubara untuk PLTU Lati.

1. Regresi harga jual listrik dengan biaya bahan bakar batubara :

$y=0,8001 x-550,95$

$\mathrm{y}=$ biaya bahan bakar batubara (Rp./kwh)

$\mathrm{x}=$ harga jual listrik (Rp./kwh)

2. Regresi biaya bahan bakar batubara dengan harga batubara :

$z=0,0633 y+1,2367$

$\mathrm{z}=$ harga batubara (USD/ton)

$\mathrm{y}=$ biaya bahan bakar batubara (Rp./kwh)

Dengan kedua persamaan di atas, diperoleh simulasi harga batubara PT Berau Coal untuk PLTU Lati adalah USD 19,96 per ton (Tabel 9) atau Rp. 12.023,5 per ton (Badan Pemeriksaan Keuangan Republik Indonesia, 2008). Harga inilah yang merupakan harga rata-rata yang dapat dikompromikan antara PT Berau Coal dan PT IPB khususnya untuk periode 2012-2015 yang belum ada kesepakatan dalam jual beli batubara yang telah berjalan. Dengan harga tersebut terdapat selisih negatif terhadap HPB. Namun demikian, nilai selisih yang negatif tersebut dapat diartikan sebagai nilai tambah kewilayahan, yaitu manfaat bagi masyarakat daerah atau lokal yang diperoleh melalui corporate social responsibility (CSR) PT Berau Coal (Soelistijo, 2013). Di samping itu, kondisi ini tidak mempengaruhi kewajiban PT Berau Coal yang telah membayar dana hasil penjualan batubara sebesar $13,5 \%$.

Tabel 9. Harga alternatif batubara

\begin{tabular}{ccc}
\hline $\begin{array}{c}\text { Harga Listrik } \\
\text { (Rp./kwh) }\end{array}$ & $\begin{array}{c}\text { Biaya Bahan } \\
\text { Bakar Batubara } \\
\text { (Rp./kwh) }\end{array}$ & $\begin{array}{c}\text { Harga } \\
\text { Batubara } \\
\text { (USD/ton) }\end{array}$ \\
\hline $1.058,25$ & 295,76 & 19,96 \\
\hline
\end{tabular}

\section{KESIMPULAN}

1. Bagi PT Berau Coal dan PT IPB, yang ingin melakukan jual beli batubara dan akan menentukan harga batubara, harus mengacu kepada peraturan perundangundangan yang berlaku untuk jangka waktu tertentu dan ditetapkan berdasarkan Peraturan Direktur Jenderal Mineral dan Batubara. Ketetapan tersebut, baik HPB maupun HDB, adalah harga batubara terendah untuk menentukan besarnya jumlah royalti yang harus dibayarkan perusahaan batubara.

2. Berdasarkan hasil simulasi terhadap cash flow PT IPB, skenario harga batubara senilai royalti HPB masih menunjukkan keekonomisan harga jual listrik PT IPB, tetapi bagi PT Berau Coal merupakan kerugian, karena hanya menutupi kewajiban terhadap pemerintah. Sedangkan berdasarkan HPB dan HDB menunjukkan ketidakekonomisan PT IPB, karena melampaui harga jual listik PT PLN (asumsi Rp. 1.300/kwh).

3. Untuk mencari win-win solution terhadap persoalan jual beli batubara antara PT Berau Coal dan PT IPB, khususnya untuk periode 2012-2015 yang belum ada kesepakatan, maka dalam menentukan harga jual batubara untuk PLTU Lati didasarkan kepada Pasal 2 dan 3 Peraturan Direktur Jenderal Mineral dan Batubara Nomor 1348.K/30/DJB/2011, yaitu harga batubara untuk pembangkit listrik mulut tambang dengan kalori lebih besar atau sama dengan $3.000 \mathrm{kkal} / \mathrm{kg}$ (gar) dapat dijual dengan harga di bawah HPB dengan menyampaikan kajian.

4. Berdasarkan hasil kajian diperoleh satu harga alternatif, yaitu USD 19,96 per ton atau Rp. 12.023,5. Harga tersebut masih di bawah harga pokok produksi PT Berau Coal. Artinya selisihnya dapat dimaknai sebagai dana pengembangan wilayah.

5. Harga batubara tersebut dapat dijadikan pedoman dalam kompromi penetapan harga batubara jual beli batubara antara PT Berau Coal dan PT IPB, khususnya untuk periode 2012-2015, yang telah berjalan.

6. Harga jual energi listrik PT IPB ke PT PLN dan PT Berau Coal hendaknya sama selama tidak ada faktor yang dapat membedakan. 


\section{UCAPAN TERIMA KASIH}

Disampaikan ucapan terima kasih kepada Dr. Miftahul Huda, Ir. Darsa Permana dan Rochman Saefudin, ST. yang telah membantu dalam penelitian dan meluangkan waktu untuk diajak diskusi dalam penulisan makalah ilmiah ini.

\section{DAFTAR PUSTAKA}

Badan Pemeriksaan Keuangan Republik Indonesia (2008) Temuan pemeriksaan atas Penerimaan Negara Bukan Pajak dan pengelolaan lingkungan pertambangan tahun anggaran 2006 dan 2007 dari Perjanjian Karya Pengusahaan Pertambangan Batubara (PKP2B) PT Berau Coal pada Departemen Energi dan Sumber Daya Mineral di Jaka. Jakarta.

Direktorat Jenderal Mineral dan Batubara (2011) Peraturan Direktur Jenderal Mineral dan Batubara Nomor 515.K/32/DJB/2011 tentang penentuan harga batubara untuk pembangkit listrik mulut tambang. Indonesia. Available at: http://jdih.esdm.go.id/peraturan/PerDirjen No. 515.K thn 2011.pdf.

Direktorat Jenderal Mineral dan Batubara (2013) Perautan Direktur Jenderal Mineral dan Batubara tentang perubahan atas Peraturan Direktur Jenderal Mineral dan Batubara Nomor 999.K/30/DJB/2011 tentang tata cara penetapan besaran biaya penyesuaian harga patokan batubara. Indonesia. Available at: http://jdih.esdm.go.id/peraturan/Perdirjen 644_2013.pdf.

Kurniawan, A. R. (2014) "The behavior of heavy metals content in coal combustion products (CCPs) and its leachate From Indonesia coal power plants," Indonesian Mining Journal, 17(2), pp. 75-86. Available at: http://jurnal.tekmira.esdm.go.id/index.php/imj /article/view/330.

Kurniawan, A. R. and Hadijah, N. R. (2012) "Comprehensive environmental evaluation of Bukit Asam power plant coal ash," Indonesian Mining Journal, 15(3), pp. 123-129. Available http://jurnal.tekmira.esdm.go.id/index.php/imj /article/view/448/313.

Kurniawan, A. R., Surono, W. and Alimano, M. (2014) "Potensi pemanfaatan limbah pembakaran batubara PLTU sebagai media tanam dalam kegiatan revegetasi lahan bekas tambang batubara," Jurnal Teknologi Mineral dan Batubara, 10(3), pp. 142-154. Available at:

http://jurnal.tekmira.esdm.go.id/index.php/mi nerba/article/view/730.

Menteri Energi dan Sumber Daya Mineral (2010) Peraturan Menteri Energi Dan Sumber Daya Mineral Nomor 17 Tahun 2010 tentang tata cara penetapan harga patokan penjualan mineral dan batubara. Indonesia. Available at: http://jdih.esdm.go.id/peraturan/Permen ESDM Nomor 07 Tahun 2017.pdf.

Menteri Energi dan Sumber Daya Mineral (2016) Peraturan Menteri Energi dan Sumber Daya Mineral Republik Indonesia Nomor 09 Tahun 2016 tentang tata cara penyediaan dan penetapan harga batubara untuk pembangkit listrik mulut tambang. Available at: http://jdih.esdm.go.id/peraturan/Permen ESDM No. 09 Tahun 2016.pdf.

Prasodjo, E., Sitorus, S. R. P., Pertiwi, S. and Putri, E. I. K. (2015) "Analisis status keberlanjutan kegiatan pertambangan batubara di Kota Samarinda Provinsi Kalimantan Timur," Jurnal Teknologi Mineral dan Batubara, 11(1), pp. 49-60. Available at: http://jurnal.tekmira.esdm.go.id/index.php/mi nerba/article/view/241.

PT Berau Coal (2016a) "Data Produksi dan pemakaian batubara PLTU Lati 2006-2015." Berau: PT Berau Coal.

PT Berau Coal (2016b) "Detail production per PIT Binungan dan Sambarata, tahun 2012-2015." Berau: PT. Berau Coal.

PT Berau Coal (2016c) "Harga batubara PT IPB tahun 2011-2015." Berau: PT Berau Coal.

PT Berau Coal (2016d) "Kronologi Batubara PLTU Lati di PT Indo Pusaka Berau." Berau: PT Berua Coal, p. 3.

PT Berau Coal (2016e) "Rekapitulasi suplay batubara ke PLTU Lati Tahun 2004-2016." Berau: PT Berau Coal.

PT Indo Pusaka Berau (2016a) "Komponen biaya operasional PLTU Lati Tahun 2012-2015." Berau: PT Indo Pusaka Berau.

PT Indo Pusaka Berau (2016b) "Pemakaian batubara, harga batubara dan royalti di PLTU Lati." PT Indo Pusaka Berau.

PT Indo Pusaka Berau (2016c) "Produksi dan penjualan listrik PLTU Lati kepada konsumen 
Tahun 2012-2015." Berau: PT Indo Pusaka Berau.

PT Indo Pusaka Berau (2016d) "Record Pemakaian Energy Listrik PLTU Tahun ke-1, tahun 20152016." Berau: PT Indo Pusaka Berau.

PT Indo Pusaka Berau (2016e) "Total biaya pengoperasian PLTU Lati Tahun 2016." Berau: PT Indo Pusaka Berau.

Saefudin, R. and Supriyantono, Y. (2012) "Nilai keekonomian batubara reject coal," Mineral dan Energi, 10(2), pp. 99-109. Available at: http://litbang.esdm.go.id/html/publikasi/5908majalah-energi-dan-mineral/5619-majalahmineral-dan-energi-juni2012/Majalah_Juni_2012_9_Nilai Keekonomian Batubara (99-110).pdf.

Soelistijo, U. W. (2013) "Beberapa indikator nilai tambah ekonomi: Sektor energi dan sumber daya mineral," Jurnal Teknologi Mineral dan Batubara, 9(1), pp. 35-49. Available at: http://jurnal.tekmira.esdm.go.id/index.php/mi nerba/article/view/777.

Suseno, T. (2013) “Kontribusi investasi pertambangan batubara terhadap produk domestik bruto Provinsi Papua Barat," Jurnal Teknologi Mineral dan Batubara, 9(3), pp. 118-134.
Suseno, T. (2017) "Analisis pola distribusi logistik dan infrastruktur batubara untuk PLTU skala kecil," Jurnal Teknologi Mineral dan Batubara, 13(1), pp. 53-72. doi: 10.30556/jtmb.Vol13.No1.2017.140.

Umar, D. F. and Hudaya, G. K. (2016) "Prediksi terjadinya slagging dan fouling pada boiler berbahan bakar batubara," in Santoso, B., Ardha, G. N., Umar, D. F., Rochani, S., Husaini, Madiutomo, N., Ningrum, N. S., Wahyudi, T., Damayanti, R., and Handayani, S. (eds.) Prosiding Kolokium Puslitbang Teknologi Mineral dan Batubara 2016. Bandung: Puslitbang tekMIRA, pp. 63-70.

Umar, D. F., Sulistyohadi, F. and Hudaya, G. K. (2015) "Coal de-ashing by solvent extraction," Indonesian Mining Journal, 18(1), pp. 11-17. Available at: http://jurnal.tekmira.esdm.go.id/index.php/imj /article/view/302.

Yunianto, B. (2015) "Analisis pengenaan pajak pertambahan nilai terhadap kontraktor perjanjian karya pengusahaan pertambangan batubara Generasi III," Jurnal Teknologi Mineral dan Batubara, 11(3), pp. 147-163. Available at: http://jurnal.tekmira.esdm.go.id/index.php/mi nerba/article/view/719. 
